\title{
Virtual World as a Complement to Hybrid and Mobile Learning
}

\author{
https://doi.org/10.3991/ijet.v15i22.14393
}

\author{
Jairo Eduardo Márquez Díaz \\ Universidad de Cundinamarca, Chía, Colombia \\ jemarquez@ucundinamarca.edu.co
}

\begin{abstract}
Virtual worlds in higher education have opened new possibilities for innovation in the teaching-learning process. In this sense, the description of the integration of this emerging technology with hybrid and mobile learning models is presented, which seeks to streamline and make flexible the access to information to the student and teacher inside and outside the classroom, intending that pedagogical didactics were more inclusive and participatory. With this in mind, a virtual world was developed as a digital tool for teaching support to students and teachers of the Faculty of Systems Engineering of the University of Cundinamarca, with a view to establishing its viability to be implemented and to demonstrate its potential as an academic resource that motivates students in their training and the teacher to develop new digital skills and competences.
\end{abstract}

Keywords-Avatar, Digital tools, Emerging technologies, Metaverse; Moodle, Open simulator, Singularity

\section{Introduction}

The virtual worlds or metaverses appears for the first time in the novel Snow Crash, published in 1992 by cyberpunk writer Neal Stephenson. [1] For [2] virtual worlds are virtual spaces for real-world recreation where users, normally under an avatar or a pseudonym, interact with other users in endless everyday situations. [3] defines metaverses as virtual environments also known as MultiUser Virtual Environments (MUVE), which have a format that derives from Massive Multiplayer Online Role-Playing Games (MMORPG) although unlike these, no they have a priori an objective or goal to meet as happens in a video game. As indicated [4] virtual worlds are fictitious constructions in which participants interact through avatars created by themselves trying to reproduce participation or real life in a virtual metaphor environment without space-time limitations.

The concept of virtual world goes beyond commercial and entertainment, which is intended to develop in the future, they are true virtual societies, where digital users or avatars are our alter ego, creating artificial communities in a digital environment that gives way to what [5] points out as digital artificial life. Consequently, the main characteristic of metaverses is based on the fact that they are created in the image and likeness not only of the programmer, but of the user, where fantasy, science fiction and 
multimedia technology combine to create fantasy and/or exotic settings, whose physical laws may or may not exist, or simply establish another extension of the real world in which we live, experiencing in the third person interactivity and immersion in a digital space that has no limit, exploring new experiences with a digital alter ego.

For [6] the metaverse is an immersive, three-dimensional, virtual and also multi-user online environment, which allows people to relate to each other, socially and economically, regardless of their location, using computer tools such as personified agents and simulation. Under this definition, it is observed that the metaverse is a virtual world to explore, where the user can interact in different ways through his avatar, exploring various contexts, even leading a double life.

As a particular case, the use of virtual worlds in higher education [7] has been a recurring theme for several years, allowing the teacher and student to explore new methods for teaching-learning process, where ICT and emerging technologies [8], [9] take a leading role in this regard, maintaining as a main premise the interactivity and immersion that are fundamental in this process. For this, the virtual worlds market has been diversifying into augmented reality applications, mirror worlds, metaverses and Lifelogging-type platforms; which can be proprietary or free, so that their developments and applications are diverse, ranging from industrial and commercial, through leisure, to education at its different levels and modalities.

\section{Characteristics of a Virtual World}

There are three fundamental characteristics of the virtual world established by [10], which are interactivity, embodiment and persistence; which have remained in force to date with certain adjustments as the technology evolves, as explained below based on the experience of the research carried out: Interactivity. The user is able to communicate with others and interact with the metaverse. This type of action is carried out through the implementation of a social network within the virtual world. Corporeity. It consists of the presence of an avatar over that space that has limits, in which it is subject to certain laws and has limited resources within the virtual world. Persistence. The program continues to function and develop even though its members are not connected. In addition, the position, conversations, property objects, etc., are saved and will be retrieved once the user is reconnected to the virtual world.

The virtual worlds versus traditional ICTs take students to an environment outside the conventional classroom, where the video game environment is no stranger to them, so their approach to this type of digital tool motivates them to inquire and thus takes advantage to bring it closer to learning [11] and knowledge in a more fun, enjoyable, interactive and immersive way. In addition, there are advantages of simulation in a virtual world contributing to cyberculture's own knowledge and learning, as [12] points out, where the visual aspect and the possibility of change in real time through the action of avatars, It is a great aid to short-term memory by amplifying imagination, individual and collective intelligence 


\section{Virtual Worlds and Emerging Technologies}

Emerging technologies offer various pedagogical tools [13] at the service of education, which tend to change the traditional paradigm of the teaching-learning process within the classroom. Thus, the development of virtual worlds integrated with teaching tools such as Blended-Learning, Mobile-Learning and the Flipped Classroom, among others, all belonging to emerging technologies and pedagogy respectively, open up endless possibilities for face-to-face, virtual and distance teaching, thus enabling a greater approach to the student and teacher to new educational proposals [14], [15]. Consequently, one aspect to consider regarding the management of virtual worlds is that it provides the student with a new study tool that integrates mobile technology and learning platforms, enabling the teacher to use new teaching methods and means.

It is worth noting the importance of the avatar in the virtual world, since it contributes, as [16] affirms, to the students acquiring skills on technological and virtual tools, which promotes the inclusion of the student in the society of the information. As for the development of the virtual world project, it was based on the OpenSimulator multiplatform. This platform is characterized by being free software under BSD license, which does not imply any cost to the developer. In addition, it offers a unique and flexible environment for the teacher interested in teaching using ICT, cooperative work, simulation and business training. [17] OpenSimulator allows those who navigate it to develop and practice skills based on the exploration of new experiences and ideas. Supports multiple clients and protocols - Accesses the same world at the same time through multiple protocols, as well as supports inworld scripts using several different languages, including LSL / OSSL, C \#, and VB.NET. [18]

As for the OpenSimulator server, it is divided into two components according to [19]: Back-end data services: consisting of user accounts, login service, assets and inventory; Simulator server: it can host unlimited virtual environments called regions. There are two modes available, which are standalone and grid. In standalone mode, these two components are combined into a single OpenSimulator process.

Based on the above characteristics, the basic skills that an avatar can perform in the virtual world are: walking, changing appearance, flying and interacting with certain objects of the metaverse, such as chairs and boards. In addition, it allows communication via social chat with other nearby avatars, among other resources, as well as teleporting from one point to another of the university facilities. This metaverse facilitates remote or virtual classes, where the teacher can upload various pedagogical resources that can be consulted by the student via the web in the first instance or by a mobile device having the virtual world at hand on their computer. With this in mind, mobile learning is combined with hybrid learning whose pedagogical resource is the inverted class [20].

In order for the virtual worlds to be fully exploited, prior training was required, where the user knew the resources available to a certain class, thus tending to make the teaching-learning process much more dynamic and interactive than the traditional one. In this sense, once the ability to manipulate the avatar has been acquired, the user, apart from moving around the university facilities, can interact with other colleagues through 
the internal social network to share academic information, thereby promoting collaborative learning, or surfing the Internet through hyperlinks arranged in the system that direct you to certain topics selected by the teacher.

\section{$4 \quad$ Method}

For the development of the virtual world, the agile SCRUM methodology [21] was used, characterized in that the work team can undertake problems in an adaptive way, committing to the delivery of products with the maximum possible value under an incremental iterative approach, which It facilitates optimizing the predictability and control of risk in each phase. In this sense, four roles were defined: Project Manager, Scrum Master, Product Owner and Scrum Team. In each development or iteration cycle (sprint) it ended with the delivery of an operational part of the product. [22]

The project manager assumed the role of software architect who represented those interested in the final product. The Scrum Master had the responsibility of maintaining harmony within the research group, ensuring that technical and administrative impediments did not affect the project. The product owner was the person who assumed the role of functional analyst, whose task was to capture and streamline the project idea. As for the Scrum Team, it played the role of making the client's project proposal a reality, which in this case was the University of Cundinamarca through the development of the product in a self-managed, self-organized and multifunctional way.

\section{$5 \quad$ Results}

There are certain particularities of the virtual worlds that make them attractive to students and teachers, since they are seen as an ideal space for the ubiquitous teachinglearning process, in which it is combined with other forms of digital learning such as mobile, hybrid and micro-learning, where the traditional pedagogical model changes from being static to dynamic represented in the inverted class and collaborative with the student being the center of this process.

A peculiarity of the developed virtual world is that you can implement various ICT resources raised specifically by the teacher, where the student has them at hand facilitating their learning. Likewise, QR codes can be incorporated to access the university's virtual classroom and applications available in the Google Play Store. The virtual world acts as an integrating element of the inverted and collaborative class [23], hybrid learning and mobile learning, where workshops and evaluations formulated on the virtual platform could be consulted either through a mobile device or computer.

With the digital resources that the virtual world has for the student in conjunction with the university's virtual Moodle platform, it facilitates their learning not only through the use of a computer, but also through any mobile device, facilitating the training process inside and outside of the classroom synchronously and asynchronously [24] With this result, a contribution is made to the change in the paradigm of traditional education [25], which converges to a flexible, dynamic, participatory and collaborative 
model mediated by ICT and emerging technologies, in this particular case from the perspective of virtual worlds.

There are some technological and pedagogical challenges [26],[27] that must be taken into account when implementing a virtual world in a subject, such as:

- The digital resources to be implemented in the metaverse must be designed, planned and/or contributed by the teacher to the administrator of the virtual world.

- Have good internet connectivity so that the metaverse does not slow down or disconnect.

- In pedagogical terms, learning in a metaverse is student-based, which encourages self-learning and collaborative learning, among others, which act as an essential component of the pedagogical model of the inverted class.

- The teacher can create the assessments directly on the virtual platform, or in another digital resource that can be added to the virtual world directly as an image tag and hyperlink.

- In the case of mobile learning, the use of applications installed on smartphones makes it easier to manage digital resources for the development of specific tasks inside or outside the classroom, which can eventually be combined with the metaverse.

- The teacher can create various digital resources [28] under the Learning by doing model, in which he can take advantage of the metaverse integrated social network to promote different types of participatory exercises.

- The integration of the teaching-learning process of the traditional classroom with technology must be gradual and methodical on the part of the teacher, since the latter acts as a mediator, guide or facilitator who accompanies the student in his training.

- A virtual world allows the incorporation of various content for learning in different formats. Therefore, the limit of creativity is subject to the teacher.

- The virtual world is characterized by its persistence, understood in the sense that the environment where the student interacts will continue to exist and develop even when not connected. That said, rules of digital coexistence called netiquettes [29] must be established, where the use of the lexicon and respect for the other, must be applied from the first moment of interaction of the participants.

\section{Conclusion}

Virtual worlds allow the exploration of new educational practices based on consolidated or in the process of being pedagogical models, promoted by emerging technologies and ICTs. The pedagogical and methodological richness that encompasses metaverses makes them ideal for both teacher and student in terms of interactivity and management of digital resources, which can be adjusted to the needs of a subject, in addition to its scalability in modify and implement other ICT tools that are required as the case may be, and even expand the metaverse by creating new regions, thereby diversifying its spectrum of applications according to academic, research or leisure needs. 
One aspect to consider when interacting with a metaverse by a neophyte teacher, is that it will be cumbersome at the beginning, however, with the interaction and practice, you can adapt to it. As for the student, he is more prepared to interact with the virtual world, which is why it is easier for him to manage the digital resources that are available in the metaverse. As [30] affirms, with adequate knowledge about the platform, students and teachers can carry out a single curriculum, a curricular and methodological adaptation for all students. Regarding the acceptance of the virtual world by students, its degree of interactivity against digital resources and navigability within it is highlighted, where types of learning such as mobile and hybrid combined with pedagogies can be exploited by the teacher. as the inverted and collaborative class among others, thus tending to make the teaching-learning process much more dynamic and participatory, thus breaking the paradigm of the teacher-centered master class, prompting it to adopt a change of attitude and aptitude towards to work and interaction with emerging technologies and pedagogies.

\section{$7 \quad$ References}

[1] Márquez, V. I. (2011). Metaversos y educación: Second Life como plataforma educativa. Revista ICONO14 Revista Científica De Comunicación Y Tecnologías Emergentes, 9(2), 151-166. https://doi.org/10.7195/ri14.v9i2.30

[2] Vázquez, C. E. \& Sevillano, G. M. (2015). Dispositivos digitales móviles en educación. El aprendizaje ubicuo. España. NARCEA, S. A. de Ediciones Madrid. 2015. Retrieved from http://narceaediciones.es/es/educacion-hoy-estudios/1046-dispositivos-digitales-movilesen-educacion.html. https://doi.org/10.21556/edutec.2017.62.1007

[3] Naya, V. B., López, R.M. \& Hernández, I. L. (2012). Metaversos formativos. Tecnologías y estudios de caso. Revista de Comunicación Vivat Academia. Año XIV N Especial, 368386. Retrieved from http://www.vivatacademia.net/index.php/vivat/article/view/67. https://doi.org/10.15178/va.2011.117e.368-386

[4] Checa, G. F. (2011). El uso de metaversos en el mundo educativo: gestionando conocimiento en Second Life. Revista de Docencia Universitaria, 8(2), 47-159. https://doi.org/10. 4995/redu.2010.6200

[5] Márquez, D. J. (2013). Nanotecnología. Ciencia a escala atómica y molecular. Ventajas y desventajas de una ciencia emergente. Madrid, España, Editorial Académica Española. Retrieved from https://bit.ly/33Ct2fq

[6] Peña, A. J. (2014). Metaversos para el master iberoamericano en educación en entornos virtuales. Revista científica electrónica de Educación y Comunicación en la Sociedad del Conocimiento. Época II Año XIII, 2(14), 227-248. Retrieved from http://eticanet.org/revista/index.php/eticanet/article/view/55. https://doi.org/10.30827/eticanet.v20i1.15523

[7] Wood, D. \& Gregory, S. (2017). The affordances of virtual worlds as authentic, culturally diverse learning environments. Wood, D. \& Gregory, S. (Ed.). Authentic Virtual World Education. Facilitating Cultural Engagement and Creativity (pp. 1-23). Washington; Springer. https://doi.org/10.1007/978-981-10-6382-4_1

[8] Márquez, D. J. (2017). Tecnologías emergentes, reto para la educación superior colombiana. Revista ingeniare, 23, 35-57. https://doi.org/10.18041/1909-2458/ingeniare.2.2882 
[9] Sosa, N. E., Salinas, J. \& De Benito, B. (2017). Emerging Technologies (ETs) in Education: A Systematic Review of the Literature Published between 2006 and 2016. International Journal of Emerging Technologies in Learning (iJET), 12(5), 128-149. https://doi.org/10. 3991/ijet.v12i05.6939

[10] Castronova, E. (2001). Virtual Worlds: A First-Hand Account of Market and Society on the Cyberian Frontier. CESifo Working Paper, 618. Retrieved from https://bit.ly/2QCXdxL

[11] Escobar, G. M. (2015). Posibilidades educativas del entorno 3D Second Life para docentes. Estudio de caso con docentes de un postgrado de la Universidad Nacional de la Plata. (Master's Thesis), Universidad de la Plata, Argentina. Retrieved from https://doi.org/10. $\underline{35537 / 10915 / 49862}$

[12] Márquez, V. I. (2010). La simulación como aprendizaje: educación y mundos virtuales". II Congreso internacional comunicación 3.0. Libro Nuevos Medios, Nueva Comunicación. Congreso llevado a cabo en Salamanca, España. Retrieved from https://comunicacion3punto0.files.wordpress.com/2011/05/comunicacion3punto0libroactas2010.pdf

[13] Oliveira, A., Behnagh, R. F., Ni, L., Mohsinah, A. A., Burgess, K. J., \& Guo, L. (2019). Emerging technologies as pedagogical tools for teaching and learning science: A literature review. Human Behavior and Emerging Technologies, 1(2), 149-160. https://doi.org/10. $1002 / \mathrm{hbe} 2.141$

[14] Álvarez, A. C. (2017). ¿Es interactiva la enseñanza en la Educación Superior? La perspectiva del alumnado. REDU, revista de docencia universitaria, 15(2), 97-112. Retrieved from https://bit.ly/3ae18cd. https://doi.org/10.4995/redu.2017.6075

[15] López, M. E., Llorent, G. V. \& Fernández, M. E. (2013). Experiencia universitaria sobre las funciones del educador/a social con tecnologías 2.0. EDUTEC. Revista Electrónica de Tecnología Educativa, 43, 1-17. Retrieved from https://pdfs.semanticscholar.org/a85f/ 1128c31dacc7049c844beb1a9ab6f982e48a.pdf https://doi.org/10.21556/edutec.2013.43.333

[16] Díaz, G. V. (2013). Entornos virtuales para el desarrollo de la educación inclusiva: Una mirada hacia el futuro desde el pasado de Second Life. RELATEC Revista Latinoamericana de Tecnología Educativa, 12(2), 67-77. Retrieved from https://dialnet.unirioja.es/servlet/articulo?codigo $=4524595$ https://doi.org/10.33349/2019.97.4450

[17] López, F. G. (2014). Producción del curso virtual sobre el uso del software. OpenSim como herramienta de apoyo didáctico. Revista de Lenguas Modernas, 21, 347-365. Retrieved from https://revistas.ucr.ac.cr/index.php/rlm/article/download/17415/16925 https://doi.org/10. 15517/rlm.v0i23.22344

[18] Swatz, M. \& Harris, E. (2014). OpenSimulator Interoperability with DRDC Simulation Tools. Compatibility Study. Ottawa On, Canada, Contract Report. DRDC-RDDC-2014C222. Retrieved from https://pdfs.semanticscholar.org/514a/c8110f0027d7b1164bbd18bed 11a6d90e986.pdf

[19] Torrecilla, M. S. (2018). Flipped Classroom: Un modelo pedagógico eficaz en el aprendizaje de Science. Revista Iberoamericana de Educación/Revista Ibero-americana de Educação, 76(1), 9-22. Retrieved from https://rieoei.org/RIE/article/view/2969/3937 https://doi.org/10. 35362/rie7612969

[20] Sutherland, J. \& Sutherland J. J. (2018). Scrum. El revolucionario método para trabajar el doble en la mitad del tiempo. Editorial Ariel.

[21] Rasnacis, A., \& Berzisa, S. (2017). Method for Adaptation and Implementation of Agile Project Management Methodology. Procedia Computer Science, 104, 43-50. https://doi.org/10.1016/j.procs.2017.01.055

[22] Castañeda, R. L, Hernández, Y. H., Bravo, B. A. \& Hernández, H. A. (2019). Flipped classroom: integración TIC en el aula. (Comp. Editor Márquez, D.). Educación, Ciencia y 
tecnologías emergentes para la generación del siglo XXI. Fusagasugá, Editorial Universidad Distrital.

[23] Van Alten, D. C. D., Phielix, C., Janssen, J., \& Kester, L. (2019). Effects of Flipping the Classroom on Learning Outcomes and Satisfaction: A Meta-Analysis. Educational Research Review. https://doi.org/10.1016/i.edurev.2019.05.003

[24] Márquez, D. J. \& Morales, E. L. (2020). Realidad aumentada como herramienta de apoyo al aprendizaje de las funciones algebraicas y trascendentes. Educación en Ingeniería, 15(29), pp. 34-41, https://doi.org/10.26507/rei.v15n29.1037

[25] De Almeida, F., de Oliveira Marques, P., Adão, J., Teixeira, Z. \& Porto, M. (2019). The Paradigms of Traditional Educational Culture in the Context of Liquid Modernity: An Empirical Study. Creative Education, 10, 784-795. https://doi.org/10.4236/ce.2019. $\underline{104058}$

[26] Makarova, E. \& Makarova, E. (2018). Blending pedagogy and digital technology to transform educational environment. International Journal of Cognitive Research in Science Engineering and Education. 6. 57-65 https://doi.org/10.5937/ijcrsee $1802057 \mathrm{~m}$

[27] Ferguson, R., Coughlan, T., Egelandsdal, K., Gaved, M., Herodotou, C., Hillaire, G., Jones, D., Jowers, I., Kukulska-Hulme, A., McAndrew, P., Misiejuk, K., Ness, I. J., Rienties, B., Scanlon, E., Sharples, M., Wasson, B., Weller, M. and Whitelock, D. (2019). Innovating Pedagogy 2019: Open University Innovation Report 7. Milton Keynes: The Open University. https://doi.org/10.3389/feduc.2019.00113

[28] Chao, T., Chen, J., Star, J. R., \& Dede, C. (2016). Using Digital Resources for Motivation and Engagement in Learning Mathematics: Reflections from Teachers and Students. Digital Experiences in Mathematics Education, 2(3), 253-277. https://doi.org/10.1007/s40751-016$\underline{0024-6}$

[29] Jamiai, A. (2019). The Role of Netiquettes in Establishing Relationships in Virtual Learning Communities. International Journal of Language and Literary Studies, 1(2). https://doi.org/10.36892/ijlls.v1i2.29

[30] Barneche, N. V., Mihura, L. R. \& Hernández, I. L. (2011). Metaversos formativos. Tecnologías y estudios de caso. Revista de Comunicación Vivat Academia, Año XIV (Especial), 368-386. Retrieved from http://www.vivatacademia.net/index.php/vivat/article/view/67. https://doi.org/10.15178/va.2011.117e.368-386

\section{Author}

Jairo E. Márquez D. PhD in Education from the University of Baja California (UBC - México), Master in Business.

Information Security, University of Barcelona (Spain), Master in Bioethics, Universidad El Bosque (Colombia), currently a research professor at the University of Cundinamarca, Professor of the New Granada Military University. Director of research groups Nanoengineering and Scientific Academic Research Activity (S@R@). Email: jemarquez@ucundinamarca.edu.co

Article submitted 2020-03-24. Resubmitted 2020-04-25. Final acceptance 2020-04-30. Final version published as submitted by the authors. 